\title{
PHYSICAL AND PSYCHOLOGICAL EFFECTS OF INTERNET ADDICTION AMONG FACULTY OF NURSING STUDENTS AT PORT SAID UNIVERSITY
}

\author{
Elsaida Gamal Aly baghdady ${ }^{1}$, Eman Saleh Shahin², Afaf Abdallah Mohamed ${ }^{3}$, \\ Sohier Goda Elsaid Abd Elrahman ${ }^{4}$ \\ Lecturer - Medical Surgical Nursing - Faculty of Nursing - Port Said university ${ }^{1}$ \\ Assistant professor - Medical Surgical Nursing - Faculty of Nursing - Port said university ${ }^{2}$ \\ Assistant professor - Family and community Health nursing — Port Said University 3 \\ Assistant professor - Psychiatry and Mental Health nursing - Faculty of Nursing - Port \\ said university ${ }^{4}$
}

\begin{abstract}
Background. The internet addiction has numerous physical and psychological effects on health of the student's faculty. Aim: Determine the physical and psychological effects of internet addiction among faculty of Nursing students at Port Said University. Setting: Faculty of Nursing, Port Said University. Subjects and Method: Design: A descriptive design was employed. Subjects: A sample of 124 students from the four academic years at faculty of Nursing, Port Said University, were involved. Tools: Three tools were used tool I. Internet use assessment sheet, tool II the Internet Addiction Test (IAT) to assess internet addiction. Tool III a measure of severity of physical and psychological symptoms as a result of using the internet scale. Results. The study results showed that headache represented a percent score of $60.48 \pm 26$. 44, while sleep problems represented percent score of $54.19 \pm 27.20$. The psychological problems percent score $43.68 \pm 29.19$. Furthermore, the moderate using the internet was $39.5 \%$ among the studied sample. Conclusion: The present study proved that headache, sleep problems and psychological symptoms (fear - depression -anxiety) respectively were the highest sever symptoms resulted from using the internet. There is significant relation between total scores of psychological symptoms, internet using scale and time of using internet. Recommendations: Improve attitude and knowledge regarding physical and/or psychological health hazards of using mobile phone and internet addiction.
\end{abstract}

Key words: Internet addiction, Physical and psychological effects. 


\section{INTRODUCTION}

The internet is a new tool that is evolving into an essential part of everyday life all over the world and its use increases especially among young people. In spite of the widely perceived importance of this tool, health care providers and educators have been aware of the negative impacts of its use especially the overuse or misuse and the related physical and psychological problems (Akin \& İskender, 2011).

The adolescents (12-19 yrs) and emerging adults (20-29 yrs) are undertaking the highest risk of overusing the Internet due to their highest recorded access to the Internet (Sadek , 2018 ). Internet addiction disorder problem is more relevant to youth (Anderson et al., 2016). Internet addiction is an online associated irresistible behavior that conflicts with normal life and triggers acute stress on family, friends, and the one's working environment. Internet dependency or internet compulsivity are other terms for Internet addiction. FOMO or Fear of missing out is an intra-personal characteristic that forces people to want to be continually in contact with the internet because they fear of passing up on an event in which they are not participating. This condition affects most of those who have social media platforms as Facebook and Instagram (Sadek ,2018).

Internet dependency can be defined as a condition that cannot overcome the desire of overusing the internet, cannot spend time without being connected to the internet, and causes the deterioration of work, social and family life Sahin \& Lok (2018) .

Internet addiction has common effects on physical health besides its effects on psychosocial situations. The physical condition that may be developed and intense by working with using the internet and computers are problems involving: bone, muscles, tendons, ligaments, skin, blood supply, joints, nerves, connective tissue, the addicted person expresses that they feel physically tired (Belanger et al., 2011).

Visual discomfort considers the most common health problem experienced by long time of using screens and internet. However, the worst common health problems caused by computers use, phones and screens include: muscles problems, obesity, respective stress injury and radiation (Reed et al., 2017; Pendse \& Zagade, 2014; Guidelines for using computers - preventing and managing discomfort, pain and injury, 2010).

However, Reed et al., (2015) and Zheng et al. (2016) state that internet addiction is a type of addiction that causes several psychosocial effects such as depression, difficulty relaxing, concentrating or sleeping, loneliness, and perceived stress.

Young users must be edified via nurses about safety as a part of their experience on common platforms. Furthermore, they should work with their educators, parents, other 
users and their communities to enhance awareness about online user safety. Additionally, nurses along with experts should work on developing messages and outreaching various communities. They have to be sure that they choose the right approach and language to grasp the communities' interest (UKCCIS, 2016).

Therefore, professional, clinical, and ethical risks of the Internet usage need to be known for nurses and clinicians. Increasingly, mental health professionals must stay cognizant of advanced trends in Internet technologies, including popular websites, social media, and smartphone apps. Additionally, they must stay cognizant of knowing why and how teens use them; teens vulnerability to the possible dangers of Internet and how to best intervene; and how to enhance family cultures and parental monitoring of technology (Rafla et al., 2014).

There is a crucial necessity to set gambling on public health agendas nationally and internationally; and to strengthen its evidence-based policy and prohibition strategies, besides extremely extend sooner intervention and medication provision. These measures may reduce harms and social costs related with gambling currently and futurely (Poli, 2017). However, a magnitude of using the internet, physical and psychological effect should be assessed as a guidance for prevention strategies and intervention treatment of internet addiction.

Internet skills are important for nursing students. During their studies they need to use the computer and Internet in finding information from web sites and using different software. Computer and Internet literacy helps student nurses to achieve their learning goals. These skills are also important for their future career. So, the ability to use Information Technology (IT) is becoming a pervasive need in nurse education. Nurses need to obtain Internet skills not only for their studies but to help patients to find relevant information for their health related questions. Derences 1. Deltsidou A, Gesouli- Voltyraki E;etal 2010

\section{Significance of study}

Internet addiction is growing problem among students of professional courses which have psychological, physical and social impact in their life. Hence awareness should be created and strategies should be developed to bring out positive outcome rather than negative which leads to destruction of human nature Franchina et al. (2018) 


\section{AIM OF STUDY:}

Determine the physical and psychological effects of internet addiction among faculty of nursing students at Port Said University.

Objectives

- Identify the level of using internet among faculty of nursing students.

- Assess the severity of physical and psychological effects of internet addiction among students.

- Find out relation between severity of physical, psychological symptoms, and the internet addiction.

\section{SUBJECTS AND METHOD}

\section{Design}

A descriptive research design was utilized in the current study.

\section{Sample}

A convenience sample of 124 students from first, second, third and fourth academic year at the faculty of Nursing/Port Said University.

Sample size calculation:

Sample size calculation: -

$$
\begin{aligned}
& \mathrm{n}=\frac{\mathrm{N} \times \mathrm{P}(1-\mathrm{P})}{\mathrm{N}-1 \times\left(\mathrm{d}^{2} \div \mathrm{z}^{2}\right)+\mathrm{P}(1-\mathrm{P})} \\
& \mathrm{n}=\frac{\mathrm{N} \times \mathrm{P}(1-\mathrm{P})}{-1 \times\left(\mathrm{d}^{2} \div \mathrm{Z}^{2}\right)+\mathrm{P}(1-\mathrm{P})} \\
& \mathrm{n}=\frac{351 \times 0.5(1-0.5)}{j 1-1 \times\left(0.05^{2} \div 1.96^{2}\right)+0.5(1-0.5)} 113
\end{aligned}
$$

\begin{tabular}{|c|c|}
\hline $\mathrm{N}=351$ & Total population \\
\hline $\mathrm{Z}$ & $\begin{array}{r}\text { Class standard corresponding to the level of significance } \\
\text { equal to } 0.95 \text { and } 1.96\end{array}$ \\
\hline $\mathrm{D}$ & The error rate is equal to 0.05 \\
\hline $\mathrm{p}$ & Ratio provides a neutral property $=0.50$ \\
\hline
\end{tabular}


When confidence level equal $80 \%$

Total sample size will be $113+(10 \%)$ drop out $=113+11=124$ student

\section{Tools and data collection}

-Data was collected via Internet use assessment sheet.

- Internet Addiction Test which developed by Young (1996).

-A measure of severity of physical and psychological symptoms as a result of using internet scale. These tools were designed by the researchers after reviewing recent books and literatures (Cheever et al; 2017; Potter et al., 2013; Timby \& Smith, 2014; Timby, 2017).

Internet use assessment sheet contains two parts; part one includes questions as students age, gender, academic year, and residence followed by part two which contain several questions about the internet use among the students. It contained questions about internet access, nature of using internet scheme and having account on social media, time spent using the phone and the internet and if this time is continuous. Tool II Internet Addiction Test (IAT) which is classified as the first certified tool to measure the Internet addiction. The IAT psychometric properties reveal that it is a reliable and valid measure. IAT measures the clients' embroilment with the computer and sorts their addictive behavior as mild, moderate, and severe ailment. Simply, it instructs the student to answer the 19-item questionnaire based upon the following five-point Likert scale. To measure the addiction level, the student has to answer the questions with one of the following: Not Applicable, Rarely, Occasionally, Frequently, Often, or Always. The score given for each of the previous answers will be $0,1,2,3,4$ or 5; respectively. After all the questions have been answered, the student adds the numbers for each response to obtain a final score. The higher the score range, the greater level of internet addiction. The total scale ranged from 0 to 90 points. However, it classified into normal from 0 to 30 , mild that ranged from 31 to 49 points, moderate ranged from 50 to 79 points, and severe addiction ranged from 80 to 95 points. Tool III a measure of severity of physical and psychological symptoms result of using internet scale, which contains 8 main physical problems caused by internet addiction and the ninth one is psychological problem every main problem contains several subproblems. (headache- sleep problems - eye problems -joint pain and finger stiffness- neck pain- lower back pain- overweight - complexion, skin problems) the sum is 41 problems, the Likert Scale consists graded range from 0 to 5, $0=$ Never, $1=$ Rarely, $2=$ Slightly, $3=$ Frequently, $4=$ much, $5=$ too much. 


\section{B-Content validity}

The needed modifications were done in tool I and tool III after it was ascertained and reviewed by a panel of nine academic expertise in the field of medical, surgical nursing and psychiatric nursing for clarity, relevance, comprehensiveness, understandable and applicable. One item was deleted, the scale contains 19 items to be answered.

\section{Reliability:}

The reliability test was done for tool III using Cronbach alpha and the tool was reliable with $=0.9$

\section{pilot study}

- The pilot study was conducted to tools I, III on $10 \%$ of subjects to test feasibility and applicability of the developed tools.

\section{Field work}

Appointments were made by academic year's coordinators at the faculty of nursing port said university to meet with the participants at lecture halls. The nature and process of the study were explained. About 45 minutes were allotted to each student to fill in the study questioners. After completion of the time, the study tools were collected and later managed and analyzed.

\section{- Administrative design}

An official letter Permission from the Dean of the faculty of Nursing was taken to implement the study in the faculty.

\section{-ETHICAL CONSIDERATION}

The researchers obtained permission from the dean of faculty. Consent was obtained orally from the students participating in the study, ensuring complete privacy and total confidentiality. Each participant has the freedom to accept to involve in the study. The researchers were assured that the information obtained is confidential and to be used only for the purpose of the study. The approval on the research study was obtained from the ethics committee of the faculty of Nursing, Port Said University.

\section{-Statistical data analysis: -}

Data was fed to the computer and analyzed using IBM SPSS software package version 20.0. (Armonk, NY: IBM Corp). Qualitative data was described using numbers and percentages. Quantitative data was described using range, minimum and maximum, mean, and standard deviation. The significance of the obtained results was judged at the $5 \%$ level. 
The used tests were:

1 - Student t-test

For normally distributed quantitative variables, to compare between two studied groups.

2 - F-test (ANOVA)

For normally distributed quantitative variables, to compare between more than two groups.

3 - Cronbach's Alpha

Reliability Statistics were assessed using Cronbach's Alpha test.

\section{RESULTS:}

Table (1): reveals that $77.4 \%$ of the study sample were females, $66.9 \%$ of them were more than 20 years old. The lowest participants in the study sample were from the first academic year, which represent $4 \%$, however the students' academic year ranged from 29.8 to $34.7 \%$. Otherwise, $66.1 \%$ mentioned that mother's occupation is a housewife, while $49.2 \%$ reported that father's occupation is an employee. Most of them reported that the family income is enough.

Table (2): showes that $87.1 \%$ of the study sample had access to the internet from the mobile, while $37.9 \%$ use laptop to access internet. Additionally, the most of them $(85.5 \%)$ use the internet for Facebook login and $79.8 \%$ use internet for scheme and research study. On the other hand, the student using the internet more than five hours was about $25.8 \%$ and student use internet from three to five hours represent $25 \%$ of the study sample. However, $72,6 \%$ of them mentioned that the using times are separate.

Table (3): shows that headache represented Min. - Max $0.0-100.0$ with a mean of $60.48 \pm 26.44$. While sleep problems represented Min. - Max $0.0-100.0$, with a mean of $54.19 \pm 27.20$, also the total physical problems were $0.0-91.18$ with a mean of $34.07 \pm$ 18.90 and psychological problems was Min. - Max and with a mean of $43.68 \pm 29.19$.

Table (4): Illiterates that the highest percent of using internet among the study sample were moderate and mild with a value of $39.5 \%$ and $36.3 \%$, respectively. However, the mean score of using the internet was $49.83 \pm 16.74$.

Table (5): showed a significant relationship between severity of psychological symptoms and student age and academic year with P-Value of 0.003 and 0.001 , respectively. However, there is only a relationship between total internet using scale and students place of residence with P-Value of 0.003 . On the other hand, there was no 
significant relation between students' sociodemographic characteristics and physical symptoms.

The table 6 shows a significant relation between total scores of psychological symptoms, internet using scale and time of using internet with P-Value of 0.015 and 0.0.

Table (1): Distribution of the studied sample according to socio- demographic characteristics $(n=124)$

\begin{tabular}{|c|c|c|c|}
\hline Q & socio- demographic characte ristics & No. & $\%$ \\
\hline & $\begin{array}{c}\text { Sex } \\
\text { Male } \\
\text { Female }\end{array}$ & $\begin{array}{l}28 \\
96\end{array}$ & $\begin{array}{l}22.6 \\
77.4\end{array}$ \\
\hline 1 & $\begin{array}{c}\text { Age (years) } \\
\leq 20 \\
>20\end{array}$ & $\begin{array}{l}41 \\
83\end{array}$ & $\begin{array}{l}33.1 \\
66.9\end{array}$ \\
\hline & $\begin{array}{l}\text { Min. - Max. } \\
\text { Mean } \pm \text { SD. }\end{array}$ & \multicolumn{2}{|c|}{$\begin{array}{l}19.0-25.0 \\
20.97 \pm 1.0\end{array}$} \\
\hline 2 & $\begin{array}{l}\text { Academic year } \\
\text { First year } \\
\text { Second year } \\
\text { Third year } \\
\text { Fourth year }\end{array}$ & $\begin{array}{c}5 \\
43 \\
39 \\
37\end{array}$ & $\begin{array}{c}4.0 \\
34.7 \\
31.5 \\
29.8\end{array}$ \\
\hline 4 & $\begin{array}{c}\text { Place of residence. } \\
\text { Urban } \\
\text { Rural } \\
\text { University city }\end{array}$ & $\begin{array}{l}18 \\
85 \\
21\end{array}$ & $\begin{array}{l}14.5 \\
68.5 \\
16.9\end{array}$ \\
\hline 5 & $\begin{array}{l}\text { Mother education } \\
\text { Read and write } \\
\text { Secondary } \\
\text { University } \\
\text { Postgraduate }\end{array}$ & $\begin{array}{c}27 \\
61 \\
34 \\
2\end{array}$ & $\begin{array}{c}21.8 \\
49.2 \\
27.4 \\
1.6\end{array}$ \\
\hline 6 & $\begin{array}{c}\text { Mother occupation } \\
\text { Employee } \\
\text { Housewife } \\
\text { Retired }\end{array}$ & $\begin{array}{c}35 \\
82 \\
7\end{array}$ & $\begin{array}{c}28.2 \\
66.1 \\
5.6\end{array}$ \\
\hline 7 & $\begin{array}{c}\text { Father education } \\
\text { Read and write } \\
\text { Secondary } \\
\text { University } \\
\text { Postgraduate }\end{array}$ & $\begin{array}{c}34 \\
54 \\
30 \\
6\end{array}$ & $\begin{array}{c}27.4 \\
43.5 \\
24.2 \\
4.8\end{array}$ \\
\hline 8 & $\begin{array}{c}\text { Father occupation } \\
\text { Employee } \\
\text { Technical } \\
\text { Free jobs } \\
\text { Retirement }\end{array}$ & $\begin{array}{l}61 \\
18 \\
34 \\
11\end{array}$ & $\begin{array}{l}49.2 \\
14.5 \\
27.4 \\
8.9\end{array}$ \\
\hline 9 & $\begin{array}{c}\text { Family income } \\
\text { Enough } \\
\text { Not enough }\end{array}$ & $\begin{array}{c}106 \\
18\end{array}$ & $\begin{array}{l}85.5 \\
14.5\end{array}$ \\
\hline
\end{tabular}


Table (2): Distribution of the studied sample according to use of internet $(n=124)$

\begin{tabular}{|c|c|c|c|}
\hline $\mathbf{Q}$ & Evaluation of internet using & No. & $\%$ \\
\hline 1 & $\begin{array}{l}\text { Internet access } \\
\text { Mobile } \\
\text { Computer } \\
\text { Laptop } \\
\text { All of them }\end{array}$ & $\begin{array}{l}108 \\
44 \\
47 \\
36\end{array}$ & $\begin{array}{l}87.1 \\
35.5 \\
37.9 \\
29.0\end{array}$ \\
\hline 2 & $\begin{array}{c}\text { Nature of using internet scheme } \\
\text { Scheme } \\
\text { Face book login } \\
\text { Research study } \\
\text { Other using (entertainment or gaming) }\end{array}$ & $\begin{array}{c}99 \\
106 \\
99 \\
31\end{array}$ & $\begin{array}{l}79.8 \\
85.5 \\
79.8 \\
25.0\end{array}$ \\
\hline 3 & $\begin{array}{c}\text { Have account on social media } \\
\text { Facebook } \\
\text { Twitter } \\
\text { Instagram } \\
\text { MySpace } \\
\text { Google plus } \\
\text { Snape chat, Pinterest, YouTube }\end{array}$ & $\begin{array}{l}115 \\
38 \\
81 \\
50 \\
24 \\
47\end{array}$ & $\begin{array}{l}92.7 \\
30.6 \\
65.3 \\
40.3 \\
19.4 \\
37.9\end{array}$ \\
\hline 4 & $\begin{array}{c}\text { Time } \\
\text { Less than one hour } \\
1-3 \text { hours } \\
3-5 \text { hours } \\
\text { More than } 5 \text { hours }\end{array}$ & $\begin{array}{l}17 \\
44 \\
31 \\
32\end{array}$ & $\begin{array}{l}13.7 \\
35.5 \\
25.0 \\
25.8\end{array}$ \\
\hline 5 & $\begin{array}{c}\text { Contentious hours' time of using internet } \\
\text { Yes } \\
\text { No }\end{array}$ & $\begin{array}{l}34 \\
90\end{array}$ & $\begin{array}{l}27.4 \\
72.6\end{array}$ \\
\hline
\end{tabular}


Table (3): Studied sample according to average of physical and psychological symptoms as a result of using internet $(n=124)$

\begin{tabular}{|c|c|c|}
\hline Items & Total score & Percent score \\
\hline $\begin{array}{l}\text { Headache } \\
\text { Min. - Max. } \\
\text { Mean } \pm \text { SD. }\end{array}$ & $\begin{array}{c}0.0-5.0 \\
3.02 \pm 1.32\end{array}$ & $\begin{array}{c}0.0-100.0 \\
60.48 \pm 26.44\end{array}$ \\
\hline $\begin{array}{l}\text { Sleep problems } \\
\text { Min. - Max. } \\
\text { Mean } \pm \text { SD. }\end{array}$ & $\begin{array}{c}0.0-5.0 \\
2.71 \pm 1.36\end{array}$ & $\begin{array}{c}0.0-100.0 \\
54.19 \pm 27.20\end{array}$ \\
\hline $\begin{array}{l}\text { Eye problems } \\
\text { Min. }- \text { Max. } \\
\text { Mean } \pm \text { SD. }\end{array}$ & $\begin{array}{c}0.0-39.0 \\
15.06 \pm 8.79\end{array}$ & $\begin{array}{c}0.0-97.50 \\
37.66 \pm 21.97\end{array}$ \\
\hline $\begin{array}{c}\text { joint pain and fingers stiffness } \\
\text { Min. }- \text { Max. } \\
\text { Mean } \pm \text { SD. }\end{array}$ & $\begin{array}{c}0.0-10.0 \\
3.66 \pm 2.92\end{array}$ & $\begin{array}{c}0.0-100.0 \\
36.61 \pm 29.24\end{array}$ \\
\hline $\begin{array}{l}\text { Neck pain } \\
\text { Min. }- \text { Max. } \\
\text { Mean } \pm \text { SD. }\end{array}$ & $\begin{array}{c}0.0-35.0 \\
9.93 \pm 8.59\end{array}$ & $\begin{array}{c}0.0-100.0 \\
28.36 \pm 24.54\end{array}$ \\
\hline $\begin{array}{l}\text { Lower back pain } \\
\text { Min. - Max. } \\
\text { Mean } \pm \text { SD. }\end{array}$ & $\begin{array}{c}0.0-45.0 \\
12.94 \pm 10.38\end{array}$ & $\begin{array}{c}0.0-100.0 \\
28.76 \pm 23.06\end{array}$ \\
\hline $\begin{array}{l}\text { Overweight } \\
\text { Min. - Max. } \\
\text { Mean } \pm \text { SD. }\end{array}$ & $\begin{array}{c}0.0-23.0 \\
9.15 \pm 5.46\end{array}$ & $\begin{array}{c}0.0-92.0 \\
36.58 \pm 21.85\end{array}$ \\
\hline $\begin{array}{c}\text { Complexion,skin problems } \\
\text { Min. - Max. } \\
\text { Mean } \pm \text { SD. }\end{array}$ & $\begin{array}{c}0.0-5.0 \\
1.45 \pm 1.64\end{array}$ & $\begin{array}{c}0.0-100.0 \\
29.03 \pm 32.79\end{array}$ \\
\hline $\begin{array}{c}\text { Total physical symptoms } \\
\text { Min. }- \text { Max. } \\
\text { Mean } \pm \text { SD. }\end{array}$ & $\begin{array}{c}0.0-155.0 \\
57.93 \pm 32.13\end{array}$ & $\begin{array}{c}0.0-91.18 \\
34.07 \pm 18.90\end{array}$ \\
\hline $\begin{array}{c}\text { Total psychological symptoms } \\
\text { Min. - Max. } \\
\text { Mean } \pm \text { SD. }\end{array}$ & $\begin{array}{c}0.0-30.0 \\
13.10 \pm 8.76\end{array}$ & $\begin{array}{c}0.0-100.0 \\
43.68 \pm 29.19\end{array}$ \\
\hline
\end{tabular}


Table (4): Distribution of the studied sample according to internet addiction (IAT) (n = 124)

\begin{tabular}{|c|c|c|}
\hline Overall using internet & No. & \% \\
\hline Normal $(0-30)$ & 16 & 12.9 \\
Mild $(31-49)$ & 45 & 36.3 \\
Moderate $(50-79)$ & 49 & 39.5 \\
Severe $(80-95)$ & 14 & 11.3 \\
\hline Total score & & \\
Min. - Max. & $49.0-95.0$ \\
Mean \pm SD. & $49.83 \pm 16.74$ \\
\hline Percent score & \multicolumn{2}{|c|}{$20.0-100.0$} \\
Min. - Max. & $52.45 \pm 17.62$ \\
Mean \pm SD. &
\end{tabular}


Table (5): Relation between severity of physical, psychological symptoms, internet using scale and socio demographic characteristics of the studied sample.

\begin{tabular}{|c|c|c|c|}
\hline \multirow[t]{2}{*}{ Demographic data } & $\begin{array}{c}\text { Physical } \\
\text { symptoms }\end{array}$ & $\begin{array}{c}\text { Psychological } \\
\text { symptoms }\end{array}$ & Ove rall using inte rnet \\
\hline & Mean \pm SD. & Mean \pm SD. & Mean \pm SD. \\
\hline Gender & & & \\
\hline Male & $65.29 \pm 31.48$ & $12.14 \pm 8.57$ & $53.96 \pm 12.61$ \\
\hline Female & $55.78 \pm 32.16$ & $13.39 \pm 8.84$ & $48.63 \pm 17.63$ \\
\hline$t(p)$ & $1.383(0.169)$ & $0.659(0.511)$ & $1.788(0.079)$ \\
\hline Age (years) & & & \\
\hline$\leq 20$ & $54.73 \pm 28.14$ & $16.39 \pm 8.92$ & $53.39 \pm 15.06$ \\
\hline$>20$ & $59.51 \pm 33.97$ & $11.48 \pm 8.26$ & $48.07 \pm 17.32$ \\
\hline $\mathbf{t}(\mathbf{p})$ & $0.777(0.439)$ & $3.032^{*}\left(0.003^{*}\right)$ & $1.677(0.096)$ \\
\hline Academic year & & & \\
\hline First year & $41.40 \pm 15.32$ & $3.20 \pm 2.17$ & $48.20 \pm 12.07$ \\
\hline Second year & $58.33 \pm 29.00$ & $17.91 \pm 8.21$ & $54.16 \pm 15.83$ \\
\hline Third year & $60.82 \pm 36.96$ & $10.82 \pm 7.72$ & $49.36 \pm 18.41$ \\
\hline Fourth year & $56.65 \pm 32.07$ & $11.27 \pm 8.36$ & $45.51 \pm 15.77$ \\
\hline $\mathbf{F}(\mathbf{p})$ & $0.562(0.641)$ & $9.498^{*}\left(<0.001^{*}\right)$ & $1.844(0.143)$ \\
\hline Place of residence & & & \\
\hline Urban & $70.0 \pm 32.62$ & $12.0 \pm 8.79$ & $39.56 \pm 11.52$ \\
\hline Rural & $56.92 \pm 32.15$ & $14.15 \pm 8.77$ & $53.05 \pm 16.81$ \\
\hline University city & $51.67 \pm 30.43$ & $9.81 \pm 8.10$ & $45.62 \pm 16.30$ \\
\hline $\mathbf{F}(\mathbf{p})$ & $1.732(0.181)$ & $2.285(0.106)$ & $6.093^{*}\left(0.003^{*}\right)$ \\
\hline Mother education & & & \\
\hline Read and write & $58.63 \pm 33.92$ & $11.04 \pm 8.90$ & $50.07 \pm 15.77$ \\
\hline Secondary & $57.54 \pm 31.01$ & $14.23 \pm 8.25$ & $51.84 \pm 17.85$ \\
\hline University & $58.50 \pm 33.80$ & $12.71 \pm 9.39$ & $46.21 \pm 15.49$ \\
\hline Postgraduate & $50.50 \pm 38.89$ & $13.50 \pm 13.44$ & $47.00 \pm 15.56$ \\
\hline $\mathbf{F}(\mathbf{p})$ & $0.045(0.987)$ & $0.859(0.464)$ & $0.841(0.474)$ \\
\hline Mother occupation & & & \\
\hline Employee & $64.49 \pm 35.20$ & $15.17 \pm 9.29$ & $50.43 \pm 17.12$ \\
\hline Housewife & $54.80 \pm 30.14$ & $12.52 \pm 8.48$ & $49.93 \pm 16.79$ \\
\hline Retired & $61.71 \pm 38.44$ & $9.57 \pm 8.32$ & $45.71 \pm 15.88$ \\
\hline $\mathbf{F}(\mathbf{p})$ & $1.168(0.314)$ & $1.745(0.179)$ & $0.232(0.793)$ \\
\hline Father education & & & \\
\hline Read and write & $62.74 \pm 34.44$ & $14.03 \pm 8.74$ & $51.56 \pm 15.64$ \\
\hline Secondary & $56.74 \pm 29.43$ & $11.94 \pm 8.45$ & $49.87 \pm 17.67$ \\
\hline University & $54.20 \pm 33.55$ & $13.10 \pm 9.56$ & $48.93 \pm 16.72$ \\
\hline Postgraduate & $60.00 \pm 39.94$ & $18.33 \pm 6.56$ & $44.17 \pm 16.71$ \\
\hline $\mathbf{F}(\mathbf{p})$ & $0.415(0.742)$ & $1.160(0.328)$ & $0.373(0.773)$ \\
\hline Father occupation & & & \\
\hline Employee & $54.69 \pm 28.86$ & $13.08 \pm 8.96$ & $49.38 \pm 14.90$ \\
\hline Technical & $59.06 \pm 30.53$ & $11.39 \pm 6.49$ & $49.28 \pm 18.20$ \\
\hline Free jobs & $60.41 \pm 35.21$ & $13.79 \pm 9.50$ & $53.29 \pm 18.33$ \\
\hline Retirement & $66.36 \pm 43.10$ & $13.91 \pm 9.21$ & $42.55 \pm 18.47$ \\
\hline $\mathbf{F}(\mathbf{p})$ & $0.529(0.664)$ & $0.326(0.806)$ & $1.208(0.310)$ \\
\hline $\begin{array}{c}\text { Family income } \\
\text { Enough }\end{array}$ & $58.01 \pm 32.64$ & $13.27 \pm 8.99$ & $49.70 \pm 16.13$ \\
\hline Not enough & $57.44 \pm 29.77$ & $12.11 \pm 7.37$ & $50.61 \pm 20.47$ \\
\hline $\mathbf{t}(\mathbf{p})$ & $0.069(0.945)$ & $0.519(0.605)$ & $0.213(0.832)$ \\
\hline
\end{tabular}

\section{t: Student t-test}

F: F for ANOVA test

$\mathrm{p}$ : $\mathrm{p}$ value for association between different categories

*: Statistically significant at $\mathrm{p} \leq 0.05$ 
Table (6): Relation between total scores of physical, psychological symptoms and overall using internet with time of using internet

\begin{tabular}{|c|c|c|c|}
\hline \multirow{2}{*}{ Time of using internet } & $\begin{array}{c}\text { Physical } \\
\text { symptoms }\end{array}$ & $\begin{array}{c}\text { Psychological } \\
\text { symptoms }\end{array}$ & $\begin{array}{c}\text { Overall using } \\
\text { internet }\end{array}$ \\
\cline { 2 - 4 } & Mean \pm SD. & Mean \pm SD. & Mean \pm SD. \\
\hline Less than one hour & $52.35 \pm 38.13$ & $12.59 \pm 9.52$ & $43.94 \pm 13.22$ \\
$1-3$ hours & $58.89 \pm 36.88$ & $10.75 \pm 7.82$ & $47.59 \pm 19.42$ \\
More than 5 hours & $51.16 \pm 23.54$ & $12.55 \pm 8.32$ & $46.58 \pm 12.40$ \\
\hline F(p) & $66.13 \pm 28.09$ & $17.16 \pm 8.97$ & $59.19 \pm 14.92$ \\
\hline
\end{tabular}

\section{F: F for ANOVA test}

$\mathrm{p}$ : $\mathrm{p}$ value for association between different categories

*: Statistically significant at $\mathrm{p} \leq 0.05$

\section{DISCUSSION}

College students are particularly a susceptible group owing to their spent time on the internet and social networking sites. So, this study is a premier step toward realizing the physical and psychological effects result of using internet.

The present study revealed that the highest percentage of internet usage between the study sample were moderate and mild, respectively. This result goes in line with Hassan et al. (2020) who mentioned that the overall prevalence of internet addiction was less than one third of the study population. Addiction rate was also less than one third in the subgroup. The most prevalent factors associated with internet addiction were durations spent daily on the internet, living setup, a separated family connection and physical activity.

The present study revealed that Facebook was the highest-ranked online activities followed by research study and scheme, finally other uses as entertainment or gaming. This goes in line with Franchina et al. (2018) and Kumar \& Mondal (2018) who said that the five highest-ranked online activities were social networking, schoolwork, entertainment, Internet gaming and shopping online. A negative relationship with teachers and between two parents, and poor academic performance showed the highest relative risk for Internet addiction.

Regarding the severity of physical and psychological symptoms resulting from using the phone and internet, this study proved that total psychological symptoms (fear, frustration, anxiety, depression, withdrawal and negative energy) were higher than 
physical. This was agreeing with Alam et al. (2014) and internet addiction impact is on psychological aspects and interpersonal aspects, followed by physical problems and work problems. However, headache was the highest symptoms was reported as a side effect related to the use of phone and internet because the electromagnetic field emitted by mobile phones.

This was agreeing with Epecik, Boyukbas et al. (2019) who mentions that headaches were to be triggered in patients with computers use more than half of patients with migraine tension headache and more than one third of tension type headache. The last type of internet users was reported with spending more time playing computer games, followed by sleep disturbance. Also, Choi et al. (2009) reported that, there was an increasing of sleep problems among more severely internet addictions as insomnia, difficult initiating sleep or maintaining sleep, early morning waking, the odds of excessive daytime sleepiness was 1.9-fold greater than mild internet addiction and 5.9-fold greater in internet addict than non-addicts.

The present study revealed that eye problems had a high physical score resulting from using the internet. This goes in line with ACC (2010) which stated that visual discomfort is a common health problem experienced by long time of using screens and internet. Signs and symptoms of visual discomfort are related to red, sore, watery, dry, feeling heavy or gritty eyes and blurred vision.

As regards to the relation between total scores of physical, psychological symptoms and overall using internet with sociodemographic characteristics, the present study revealed that there was a significant relation between the age, academic year and severity of psychological problems. These results agree with Xin et al. (2018) who reported that older grade students reported more internet addiction rate. Moreover, there was a significant relation between place of rural residence and university city and overall use of internet the higher. This was explained by young student living away from parents and loss family or parental control and living in rural areas. It was also noticed that the students were spending their time in entertainment, gaming, online shopping and social media platforms.

The present study showed that about one third of the study sample spend 1-3 hours per day and one quarter used the internet for 5 hours and more. This result goes in the line with Hassan et al. (2020) who reported that more than one third of internet users like to stay on the internet for more than 3 hours per day.

The present study showed a significant relation between the total score of psychological symptoms, internet using scale and time of using internet. This was 
consistent with Sharma \& Sharma (2018) who mentioned that students with higher levels of internet addiction are more likely to be low in psychological well-being PWB. This suggests that PWB was influenced by internet addiction; and shows a negative association between it and internet addiction.Also, El-Zeftawy \& El- Mezayen (2017) proved in their study that the overall score on the Internet addiction scale; the average hours spent weekly on the Internet; years of using the Internet; and the number of periods spent on the internet during school times and holidays; are positively correlated.

\section{CONCLUSION}

The present study proved that headache, sleep problems and psychological symptoms, respectively were the highest sever symptoms resulted from using internet. Internet use of moderate degree was the highest among students. There was a significant relation between total scores of psychological symptoms and level of internet addiction and time of using the internet.

\section{RECOMMENDATIONS}

- Health care teams must educate parents and teens to identify signs of internet addiction and different ways to lower the internet time usage by increasing physical activity and involving them in outdoor activities.

- Practitioners and nurses must enumerate a new skill set; identify the unfavorable technological effects on teens' physical and psychological health and the at-risk patients' vulnerabilities; and guide parents and teens about the possible interventions.

- Nurses must implement educational programs with guidelines to improve knowledge and attitude regarding health hazards as physical - Psychological of mobile phone, internet use. Also, ensure the association between knowledge and attitude with various demographic variables among the faculty students.

- Educate users of internet, parents, educators, and communities and promote their awareness about online safety. Work with experts to help in promoting continuous messages that can reach various communities.

\section{REFERENCES:}

ACC. (2010). Safely using computers at work | WorkSafe.

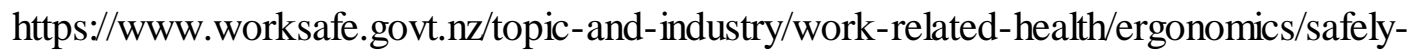
using-computers-at-work/ 
Akin, A., \& İskender, M. (2011). Internet addiction and depression, anxiety and stress. International Online Journal Of Educational Sciences, 3(1), 138-148. Retrieved 29 September 2020, from.

Alam, S., Hashim, N., Ahmad, M., Wel, C., Nor, S., \& Omar, N. (2014). Negative and positive impact of internet addiction on young adults: EmpericialEmpirical study in Malaysia. Intangible Capital, 10(3), 619-638. https://doi.org/10.3926/ic.452

Anderson, E., Steen, E., \& Stavropoulos, V. (2016). Internet use and Problematic Internet Use: a systematic review of longitudinal research trends in adolescence and emergent adulthood. International Journal of Adolescence Andand Youth, 22(4), 430-454. https:/doi.org/10.1080/02673843.2016.1227716

Belanger, R., Akre, C., Berchtold, A., \& Michaud, P. (2011). A U-Shaped Association Between Intensity of Internet Use and Adolescent Health. PEDIATRICS, 127(2), e330-e335. https://doi.org/10.1542/peds.2010-1235

Cheever, K., Hinkle, J., \& Smeltzer, S. (2017). Brunner \& Suddarth's textbook of medical-surgical nursing 12th ed. Chapter 58 assessment and management of patients with eye disorder . pp. 582-583, 586). Philadelphia.

Choi, K., Son, H., Park, M., Han, J., Kim, K., Lee, B., \& Gwak, H. (2009). Internet overuse and excessive daytime sleepiness in adolescents. Psychiatry and Clinical Neurosciences, 63(4), 455-462. https://doi.org/10.1111/j.1440-1819.2009.01925.x

Derences 1. Deltsidou A, Gesouli- Voltyraki E, Mastrogiannis D, Noula M (2010) Undergraduate nursing students' computer skills assessment: a study in Greece. Health Sci J 4:182-188.

Daniel WW(1999) . Biostatistics :A foundation for analysis in the health siences 7 edition Newyork john wiely \& Sons

El-Zeftawy, A., \& El- Mezayen, S. (2017). Incentives for Using Internet and Its Addiction among Adolescents in Rural Area in Tanta City, Egypt. IOSR Journal Ofof Nursing Andand Health Science, 6(3), 79-91. https://doi.org/10.9790/1959-0603077991

EPECİK BÖYÜKBAŞ, İ., ÇITAK KURT, A., TURAL HESAPÇIOĞLU, S., \& UĞURLU, M. (2019). Relationship between headache and Internet addiction in children. TURKISH JOURNAL OF MEDICAL SCIENCES, 49(5), 1292-1297. https//doi.org/10.3906/sag-1806-118 
Franchina, V., Vanden Abeele, M., Van Rooij, A., Lo Coco, G., \& De Marez, L. (2018). Fear of Missing Out as a Predictor of Problematic Social Media Use and Phubbing Behavior among Flemish Adolescents. International Journal Ofof Environmental Research Andand Public Health, 15(10), 2319. https://doi.org/10.3390/ijerph15102319

Hassan, T., Alam, M., Wahab, A., \& Hawlader, M. (2020). Prevalence and associated factors of internet addiction among young adults in Bangladesh. Journal Ofof The Egyptian Public Health Association, 95(1), 3. https:/doi.org/10.1186/s42506-0190032-7

Kumar, M., \& Mondal, A. (2018). A study on Internet addiction and its relation to psychopathology and self-esteem among college students. Ind Psychiatry J,27(1), 61-66. https $/ /$ doi.org/10.4103/ipj.ipj_61_17

Pawłowska, B., Zygo, M., Potembska, E., Kapka-Skrzypczak, L., Dreher, P., \& Kędzierski, Z. (2015). Prevalence of Internet addiction and risk of developing addiction as exemplified by a group of Polish adolescents from urban and rural areas. Annals Ofof Agricultural Andand Environmental Medicine, 22(1), 129-136. https $/ /$ doi.org/10.5604/12321966.1141382

Pendse, N., \& Zagade, T. (2014). Knowledge and Attitude Regarding Health Hazards of Mobile Phone Users among the Junior College Students. International Journal Of Science And Research (IJSR), 3(5), 554-561.

Poli, R. (2017). Internet addiction update: diagnostic criteria, assessment and prevalence. Neuropsychiatry, 7(1), 4-8. https//doi.org/10.4172/Neuropsychiatry.1000171

Potter, P., Perry, A., Stockert, P., \& Hall, A. (2013). Fundamentals of Nursing 8th ed. Chapter 16. health and wellness. pp. 258-267 Elsevier Mosby.

Rafla, M., Carson, N., \& DeJong, S. (2014). Adolescents and the Internet: What Mental Health Clinicians Need to Know. Current Psychiatry Reports, 16(9), 472. https:/doi.org/10.1007/s11920-014-0472-x

Reed, P., Osborne, L., Romano, M., \& Truzoli, R. (2015). Higher impulsivity after exposure to the internet for individuals with high but not low levels of self-reported problematic internet behaviours. Computers Inin Human Behavior, 49, 512-516. https:/doi.org/10.1016/j.chb.2015.03.064

Reed, P., Romano, M., Re, F., Roaro, A., Osborne, L., Viganò, C., \& Truzoli, R. (2017). Differential physiological changes following internet exposure in higher and lower 
problematic internet $\quad$ users. PLOS ONE, 12(5), e0178480. https:/doi.org/10.1371/journal.pone.0178480

Sahin, M., \& Lok, S. (2018). Relationship between Physical Activity Levels and Internet Addiction of Adults. Journal Ofof Depression Andand Anxiety,7(2), 1-4. https:/doi.org/10.4172/2167-1044.1000310

Sharma, A., \& Sharma, R. (2018). Internet addiction and psychological well-being among college students: A cross-sectional study from Central India. Journal Ofof Family Medicine Andand Primary Care, 7(1), 147. https://doi.org/10.4103/jfmpc.jfmpc_189_17

Timby, B. (2017). Fundamental Nursing Skills and Concepts (11th ed., pp. 428430). Walters Kluwer, Lippincott Williams \& Wilkins.

Timby, B., \& Smith, N. (2014). Introductory medical-surgical nursing (11th ed., p. 317). Walters Kluwer, Lippincott Williams and Wilkins.

ACC. (2010). Safely using computers at work | WorkSafe. https $/ /$ www.worksafe.govt.nz/topic-and-industry/work-related-health/ergonomics/safelyusing-computers-at-work/

UKCCIS. (2016). Child Safety Online A Practical Guide for Providers of Social Media and Interactive Services. www.saferinternet.org.uk/research.

Xin, M., Xing, J., Pengfei, W., Houru, L., Mengcheng, W., \& Hong, Z. (2018). Online activities, prevalence of Internet addiction and risk factors related to family and school among adolescents in China. Addictive Behaviors Reports, 7, 14-18. https $/ /$ doi.org/10.1016/j.abrep.2017.10.003

YOUNG, K. (1996). Internet Addiction: The Emergence of a New Clinical Disorder. Cyberpsychology \& Behavior Journal, 1(3), 237-244. https//doi.org/10.1089/cpb.1998.1.237

Zheng, Y., Wei, D., Li, J., Zhu, T., \& Ning, H. (2016). Internet Use and Its Impact on Individual Physical Health. IEEE Access, 4, 5135-5142. https:/doi.org/10.1109/access.2016.2602301

باسم صـاد. (2018). الشباب تحذر ادمان التكنولوجيا يسبب الفومو. مجلة الشباب مؤسسة الاهرام، 42(475)، 14 -16. 
التاثير ات الجسمانية و النفسية لادمان الانترنت بين طلاب كلية التمريض فى جامعة بورسعيد

\section{الخلاصة}

يسبب ادمان الانترنت الكثير من المشكلات الجسمانية والنفسية والتى تؤثر على صحة المستخدمين له من طلاب الكلية وتهدف هذه الدر اسة الى تحديد التاثيرات الجسمانية والنفسية نتيجة ادمان الانترنت بين طلاب كلية التمريض - جامعة بورسعيد ـ واجريت هذة الدر اسة فى كلية التمريض - جامعة بورسعيد وهى دراسة وصفية واشتملت على عينة مكونة من 124 طالب وطالبة من الفرق الدراسية الاربعة فى الكلية واشتملت ادوات جمع البيانات على ثلاث استمارات الاستمارة الاولى استمارة تقييم استخدام الانترنت و الاستمارة الثانية هى اختبار ادمان الانترنت وهى اختى ولتبار قياس ادمان الانترنت بين مستخدميه ز اما الاداة الثالثة وهى مقياس شدة الاعراض الجسمانية والنفسية نتيجة استخدام

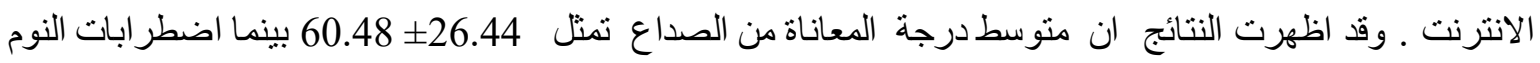

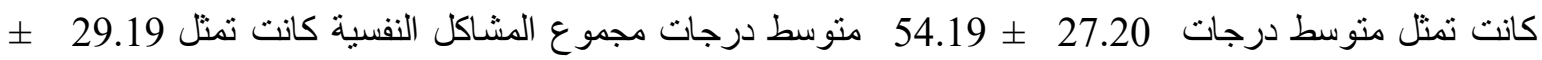

كما اظهرت النتائج ان $\%$ \% 39.5 من الطلاب كانت استخدامها الانترنت متوسط ب مقياس ادمان الانترنت ( الخلاصة اثبت هذه الدراسة ان الاعر اض الاتية الصداع و اضطر اب النوم والمشاكل النفسية مثل الخوف (IAT) ـ الاكئباب - القلق النفسى كانت اكثر شدة نتيجة استخدام الانترنت ؛ ايضا وجدت علاقة ذات دلالة احصائية بين شدة المشاكل النفسية و ادمان الانترنت و الوقت المستخدم للانترنت ـ لذلك من توصيات البحث ـ تحسين وزيادة المعلومات والسلوكيات عن المخاطر المترتبة من استخدام المفرط للانترنت والهواتف المحمولة . 